\title{
Outbreak of NDM-1-producing Acinetobacter baumannii in France, January to May 2013
}

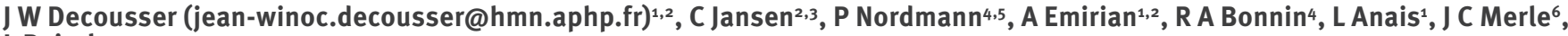
L Poirel ${ }^{4,5}$

1. Department of Virology, Bacteriology - Infection Control, Parasitology -Mycology, Assistance Publique - Hôpitaux de Paris (AP-HP), University Hospital Henri Mondor, Créteil, France

2. University Paris East Créteil (UPEC), Faculty of Medicine, Créteil, France

3. Infection Control, Prevention and Epidemiology Unit, AP-HP, University Hospital Henri Mondor, Créteil, France

4. INSERM U914 ‘Emerging Antibiotic Resistance', Le-Kremlin-Bicêtre, France

5. Medical and Molecular Microbiology Unit, Department of Medicine, Faculty of Science, University of Fribourg, Fribourg, Switzerland

6. Department of Anaesthesiology, AP-HP, University Hospital Henri Mondor, Créteil, France

Citation style for this article:

Decousser JW, Jansen C, Nordmann P, Emirian A, Bonnin RA, Anais L, Merle JC, Poirel L. Outbreak of NDM-1-producing Acinetobacter baumannii in France, January to May 2013. Euro Surveill. 2013;18(31):pii=20547. Available online: http://www.eurosurveillance.org/ViewArticle.aspx?Articleld=20547

Article submitted on 23 July 2013 / published on 01 August 2013

We report the first outbreak of carbapenem-resistant NDM-1-producing Acinetobacter baumannii in Europe, in a French intensive-care unit in January to May 2013. The index patient was transferred from Algeria and led to the infection/colonisation of five additional patients. Concurrently, another imported case from Algeria was identified. The seven isolates were genetically indistinguishable, belonging to ST85. The bla $a_{\mathrm{NDM}-1}$ carbapenemase gene was part of the chromosomally located composite transposon Tn125. This report underscores the growing concern about the spread of NDM-1-producing $A$. baumannii in Europe.

\section{Background}

The emergence and spread of New-Delhi metallo-betalactamase (NDM)-producing Gram negative isolates constitutes a new wave of multidrug-resistant (MDR) bacteria [1]. First identified from Enterobacteriaceae, the $b a_{\mathrm{NDM}}$ gene has since been identified in non-fermenting bacterial species such as Pseudomonas aeruginosa and Acinetobacter baumannii [2,3]. Considering its ability to be the source of nosocomial outbreaks, carbapenem-resistant $A$. baumannii (AB) represents a threat for critically ill hospitalised patients [4]. We report here the first outbreak of NDM-1-producing $A B$ in Europe, which occurred in a French surgical intensive-care unit in January to May 2013.

\section{Outbreak description}

The index case (Patient 1) was a female patient in her early 80 s suffering from end-stage cirrhosis. She originated from Algeria but lived mostly in France. During a stay in Algeria in December 2012, she was admitted into a private hospital in the city of Tizi Ouzou following renal failure, which required dialysis. After one month in hospital, she was repatriated to France due to liver decompensation. On 18 January 2013, she was admitted to a 15 -bed surgical intensive-care unit of a tertiary care university hospital in a Paris suburb. In accordance with local and national policy, she was screened on admission for carriage of MDR bacteria. Rectal screening revealed MDR-A. baumannii (MDR-AB) (Isolate 1) that was susceptible only to amikacin, netilmicin and colistin (Table). The same day, she was intubated for respiratory failure. Protected distal bronchial brushing yielded a culture of MDR-AB with the same antibiotic resistance profile. A combination of intravenous tigecycline and amikacin was given. On 24 January, she developed multivisceral failure and died four days later. During the following days, three additional patients with MDR-AB infection and/or colonisation were identified in the same unit. A cirrhotic male patient in his mid-6os (Patient 2) - who had been hospitalised since 3 January 2013 and confirmed free of MDR bacteria on admission - developed a ventilator-associated pneumonia on 26 January. Culture of a distal protected specimen yielded MDR-AB (Isolate 2). This patient was successfully treated by a combination of tigecycline and amikacin and was extubated two days later. Patient 3 was a male liver-transplant patient in his mid-6os who was not colonised on admission but developed a dialysis catheter-related bloodstream infection due to a MDR-AB on 28 January (Isolate 3). Imipenem and amikacin combination was prescribed but the patient died of haemorrhagic shock before antibacterial susceptibility results could be obtained. Patient 4 was a dual renal- and liver-transplant female patient in her late $40 \mathrm{~s}$ from whom an abdominal drain yielded an MDR-AB culture on 2 February (Isolate 4). This patient recovered without receiving any antibiotic therapy and was discharged from the hospital on 11 February.

Two weeks after the admission of the index case, a woman in her early 80 s (Patient 5 ) suffered from a cerebrovascular accident and was repatriated from the 
Antimicrobial susceptibility of carbapenem-resistant NDM-1-producing Acinetobacter baumannii isolates, France, January-May 2013 (n=7)

\begin{tabular}{|c|c|c|c|c|c|c|c|}
\hline \multirow[t]{2}{*}{ Antibiotic } & \multicolumn{7}{|c|}{$\begin{array}{c}\text { Isolates } \\
\text { MIC }[\mu \mathrm{g} / \mathrm{mL}]\left(\mathrm{S} / \mathrm{I} / \mathrm{R}^{\mathrm{a}}\right)^{\mathrm{b}}\end{array}$} \\
\hline & 1 & 2 & 3 & 4 & 5 & 6 & 7 \\
\hline $\begin{array}{l}\text { Ampicillin- } \\
\text { sulbactam }\end{array}$ & 16 & 24 & 16 & 24 & 24 & 32 & 192 \\
\hline $\begin{array}{l}\text { Ticarcillin- } \\
\text { clavulanic acid }\end{array}$ & $>256$ & $>256$ & $>256$ & $>256$ & $>256$ & $>256$ & $>256$ \\
\hline Piperacillin & $>256$ & $>256$ & $>256$ & $>256$ & $>256$ & $>256$ & $>256$ \\
\hline $\begin{array}{l}\text { Piperacillin- } \\
\text { tazobactam }\end{array}$ & $>256$ & $>256$ & $>256$ & $>256$ & $>256$ & $>256$ & $>256$ \\
\hline Aztreonam & $>256$ & $>256$ & $>256$ & $>256$ & $>256$ & $>256$ & 192 \\
\hline Ceftazidime & $>256$ & 2256 & $>256$ & $>256$ & $>256$ & $>256$ & $>256$ \\
\hline Cefepime & $>256$ & 2256 & $>256$ & $>256$ & $>256$ & $>256$ & $>256$ \\
\hline Meropenem & $\begin{array}{l}132 \\
(R)\end{array}$ & $\begin{array}{l}132 \\
(R)\end{array}$ & $\begin{array}{l}132 \\
(R)\end{array}$ & $\begin{array}{l}132 \\
(R)\end{array}$ & $\begin{array}{l}132 \\
(R)\end{array}$ & $\begin{array}{l}132 \\
(R)\end{array}$ & $\begin{array}{l}\text { >32 } \\
\text { (R) }\end{array}$ \\
\hline Imipenem & $\begin{array}{l}132 \\
(R)\end{array}$ & $\begin{array}{l}132 \\
(\mathrm{R})\end{array}$ & $\begin{array}{l}>32 \\
(\mathrm{R})\end{array}$ & $\begin{array}{l}132 \\
(\mathrm{R})\end{array}$ & $\begin{array}{l}132 \\
(\mathrm{R})\end{array}$ & $\begin{array}{l}132 \\
(R)\end{array}$ & $\begin{array}{l}>32 \\
(\mathrm{R})\end{array}$ \\
\hline $\begin{array}{l}\text { Imipenem/ } \\
\text { imipenem + } \\
\text { EDTA ratiob }^{\text {bDT }}\end{array}$ & 96 & 96 & 64 & 128 & 96 & 64 & 128 \\
\hline Doripenem & $\begin{array}{l}>32 \\
(R)\end{array}$ & $\begin{array}{l}132 \\
(R)\end{array}$ & $\begin{array}{l}132 \\
(R\end{array}$ & $\begin{array}{l}132 \\
(R)\end{array}$ & $\begin{array}{l}132 \\
(R)\end{array}$ & $\begin{array}{l}132 \\
(R)\end{array}$ & $\begin{array}{l}>32 \\
(\mathrm{R})\end{array}$ \\
\hline Ciprofloxacin & $\begin{array}{l}>32 \\
(R)\end{array}$ & $\begin{array}{l}132 \\
(R)\end{array}$ & $\begin{array}{l}132 \\
(R)\end{array}$ & $\begin{array}{l}132 \\
(R)\end{array}$ & $\begin{array}{l}132 \\
(R)\end{array}$ & $\begin{array}{l}132 \\
(R)\end{array}$ & $\begin{array}{l}>32 \\
(R)\end{array}$ \\
\hline Gentamicin & $\begin{array}{l}32 \\
(R)\end{array}$ & $\begin{array}{l}24 \\
(R)\end{array}$ & $\begin{array}{l}24 \\
(R)\end{array}$ & $\begin{array}{l}32 \\
(R)\end{array}$ & $\begin{array}{l}24 \\
(R)\end{array}$ & $\begin{array}{l}32 \\
(R)\end{array}$ & $\begin{array}{l}64 \\
(R)\end{array}$ \\
\hline Amikacin & $\begin{array}{l}8 \\
(S)\end{array}$ & $\begin{array}{l}12 \\
(I)\end{array}$ & $\begin{array}{c}8 \\
(S)\end{array}$ & $\begin{array}{c}8 \\
(S)\end{array}$ & $\begin{array}{l}8 \\
(S)\end{array}$ & $\begin{array}{l}8 \\
(S)\end{array}$ & $\begin{array}{l}64 \\
(\mathrm{R})\end{array}$ \\
\hline Tobramycin & $\begin{array}{l}24 \\
(R)\end{array}$ & $\begin{array}{l}32 \\
(R)\end{array}$ & $\begin{array}{l}24 \\
(R)\end{array}$ & $\begin{array}{l}24 \\
(R)\end{array}$ & $\begin{array}{l}24 \\
(R)\end{array}$ & $\begin{array}{l}32 \\
(R)\end{array}$ & $\begin{array}{l}64 \\
(R)\end{array}$ \\
\hline Netilmicin & $\begin{array}{c}0.75 \\
(S)\end{array}$ & $\begin{array}{l}1.5 \\
(\mathrm{~S})\end{array}$ & $\begin{array}{l}0.5 \\
\text { (S) }\end{array}$ & $\begin{array}{l}0.75 \\
(S)\end{array}$ & $\begin{array}{c}0.75 \\
(\mathrm{~S})\end{array}$ & $\begin{array}{l}0.75 \\
(\mathrm{~S})\end{array}$ & $\begin{array}{c}1 \\
(\mathrm{~S})\end{array}$ \\
\hline Tetracycline & 4 & 2 & 2 & 2 & 2 & 2 & 2 \\
\hline Tigecycline & 0.75 & 1 & 1 & 1 & 1 & 0.25 & 0.38 \\
\hline Colistin & $\begin{array}{c}0.125 \\
(\mathrm{~S})\end{array}$ & $\begin{array}{c}0.19 \\
(\mathrm{~S})\end{array}$ & $\begin{array}{l}0.38 \\
\text { (S) }\end{array}$ & $\begin{array}{l}0.25 \\
(\mathrm{~S})\end{array}$ & $\begin{array}{l}0.38 \\
(\mathrm{~S})\end{array}$ & $\begin{array}{l}0.25 \\
\text { (S) }\end{array}$ & $\begin{array}{c}0.38 \\
(\mathrm{~S})\end{array}$ \\
\hline $\begin{array}{l}\text { Trimethoprim- } \\
\text { sulfamethoxazole }\end{array}$ & $\begin{array}{l}>32 \\
(R)\end{array}$ & $\begin{array}{l}>32 \\
(R)\end{array}$ & $\begin{array}{l}>32 \\
(\mathrm{R})\end{array}$ & $\begin{array}{l}132 \\
(R)\end{array}$ & $\begin{array}{l}>32 \\
(R)\end{array}$ & $\begin{array}{l}>32 \\
(R)\end{array}$ & $\begin{array}{r}>32 \\
(\mathrm{R})\end{array}$ \\
\hline Fosfomycin & 256 & 384 & 384 & 192 & 256 & 256 & 192 \\
\hline Rifampicin & 6 & 6 & 6 & 6 & 6 & 32 & 8 \\
\hline
\end{tabular}

MIC: mimimum inhibitory concentration; NDM: New-Delhi metallo-beta-lactamase.

Susceptible/Intermediary Resistant/Resistant categories from the European Committee on Antimicrobial Susceptibility Testing (EUCAST) guidelines [5], if determined.

b Except for the imipenem/imipenem + EDTA ratio. The ratio was considered significant if $>4$. same Algerian county that Patient 1 was repatriated from (but from a different healthcare facility) to the emergency unit of our hospital. A screening test performed on admission identified MDR-AB (Isolate 5).

Two months after this first cluster of five patients with MDR-AB, two additional patients free of MDR bacteria on admission to the surgical intensive-care unit described acquired a MDR-AB during their stay in this unit. A woman in her late 50 s (Patient 6) was admitted to the surgical intensive-care unit on 6 April and placed in the room where the index case had stayed. This patient was found positive for MDR-AB on 15 April in specimens from a catheter and the respiratory tract (Isolate 6). She was treated with intravenous tigecycline and aerosolised colistin. She underwent successful liver transplantation on 22 April and recovered well. The last patient (Patient 7) was a man in his late $50 \mathrm{~s}$ admitted to the surgical intensive-care unit on 3 April for a liver transplant and from whom a rectal swab yielded MDR-AB a month later (Isolate 7). The patients' duration of hospital stay, time of infection and/or colonisation and location in the hospital are reported in Figure 1.

\section{Laboratory analysis}

Identification of the seven MDR-AB strains at the species level was confirmed by $16 \mathrm{~S}$ RNA sequencing (data not shown). Their antimicrobial susceptibilities were tested by minimum inhibitory concentration (MIC) determination (Etest, bioMérieux, France) (Table) and interpreted according to EUCAST guidelines [5]. All isolates exhibited a high level of resistance to penicillins, broad-spectrum cephalosporins, carbapenems, fluoroquinolones and trimethoprim-sulfamethoxazole. Those isolates remained susceptible only to netilmicin, colistin and amikacin. The production of a class B carbapenemase was suspected by the positive results of the imipenem/imipenem plus EDTA test using MIC double strips (Etest, bioMérieux, France) (Table 1) and confirmed by UV spectrophotometry [6]. Carbapenemase genes were screened by PCR as described and the bla $a_{\mathrm{NDM}-1}$ gene was amplified in the seven isolates [7]. Genotypic comparison by pulsed-field gel electrophoresis using restriction enzyme Smal revealed an indistinguishable profile (data not shown). Diversilab (bioMérieux, France) analysis and multilocus sequence typing (MLST) typing confirmed that these isolates were clonally related and belonged to the same sequence type, ST85 (Figure 2) [8]. The genetic environment of bla $a_{\mathrm{NDM}-1}$ was investigated as previously described [8] and showed that it was located in the composite transposon Tn125 made of two copies of insertion sequence (IS) ISAba125.

\section{Discussion}

Carbapenem-resistant $A$. baumannii are a source of deep concern due to their multidrug resistance pattern and the ability of this bacterial species to persist in the environment $[4,9,10]$. Intensive-care units are particularly susceptible to outbreaks associated with 
Timeline of patients infected/colonised with carbapenem-resistant NDM-1-producing Acinetobacter baumannii hospitalised in a surgical intensive-care unit, Créteil, France, January-May $2013(\mathrm{n}=6)$

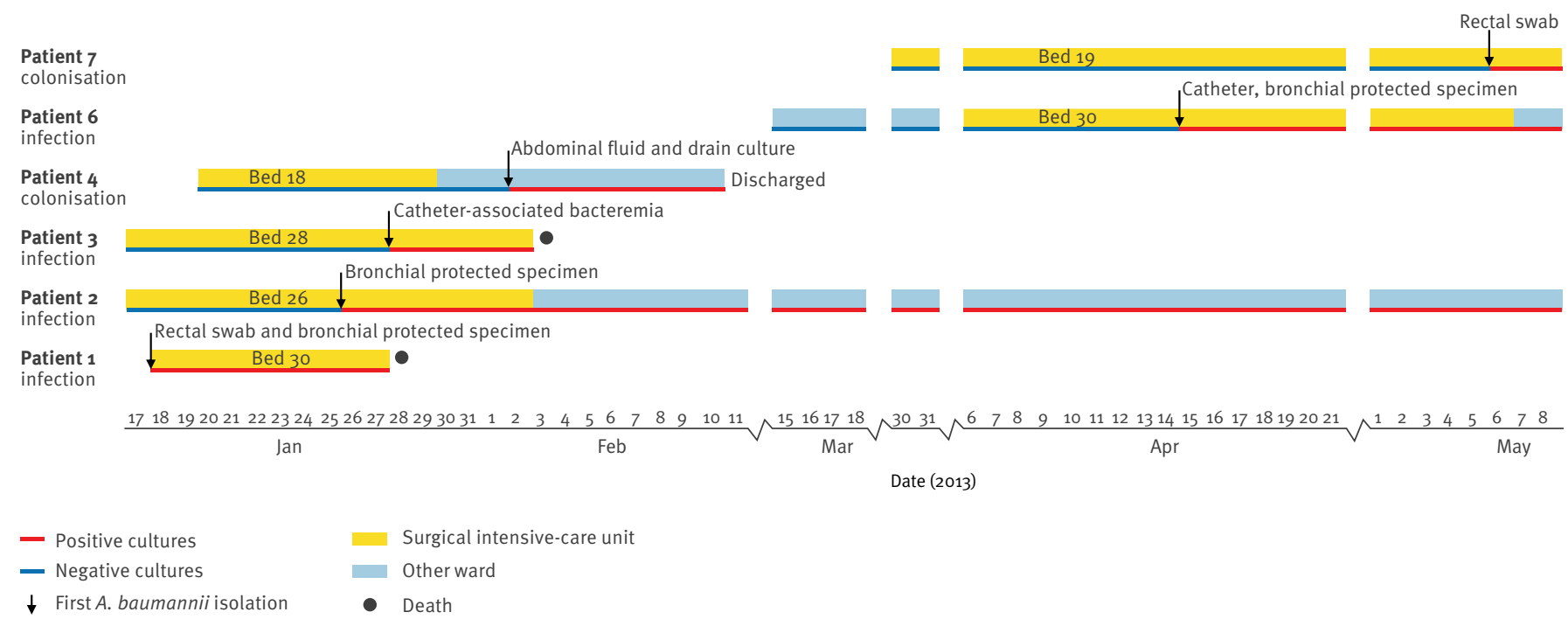

NDM: New-Delhi metallo-beta-lactamase.

\section{FIGURE 2}

Results of Diversilab and multilocus sequence typing analysis of isolates from patients infected/colonised with carbapenem-resistant NDM-1-producing Acinetobacter baumannii hospitalised in a surgical intensive-care unit, Créteil, France, January-May 2013 (n=6)

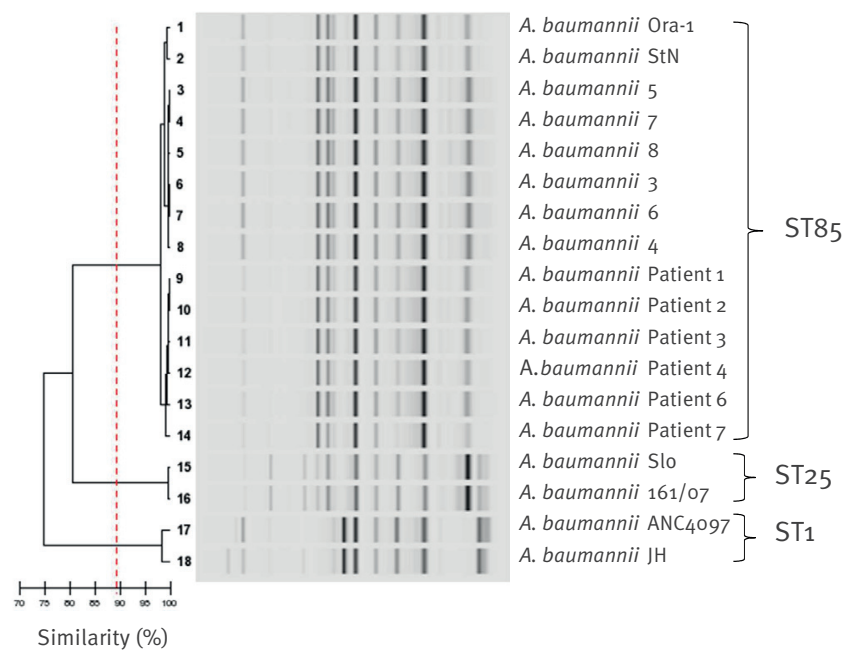

NDM: New-Delhi metallo-beta-lactamase.

The isolates from the hospitalised patients were compared with a collection of characterised strains $[8,17]$. A similarity line $(89.4 \%)$ shows the cut-off to separate different clones.
MDR-AB: it is sometimes difficult for them to adhere strictly to infection control measures when patients require a high and persistent care-load. Four years ago, the same hospital faced a hospital-wide outbreak of MDR-AB colonisations and infections due to the importation of an index case from Tahiti [11]. Despite this experience and the implementation in 2010 at the national and local level of strict measures on hospital admission to detect, screen and place under contactisolation precautions repatriated patients, another outbreak linked to the admission of a patient previously hospitalised abroad again occurred [12].

Since 2010, NDM-producing MDR-AB has been identified in various parts of the world, in particular in North Africa and the Middle East [8,13-17]. A series of imported cases have been identified recently in Europe, such as in the Czech Republic, Germany, Slovenia, Switzerland and Belgium $[8,13,14,17]$. In France, the emergence of an NDM-1-producing MDR-AB strain originating from North Africa was recently highlighted $[15,17]$. We describe here the first outbreak associated with the importation of this NDM-1-producing A. baumannii clone ST85 in Europe. This report underlines the need for dedicated measures for patients previously treated in a hospital located in a 'high risk' geographical area. Such measures (e.g. screening for colonisation/infection with MDR organisms and isolation nursing) should be maintained until the screening for colonisation/infection (e.g. using rectal, throat and wound swabs) has shown that these patients are free of MDR organisms. Because of intermittent carriage or lack of sensitivity of the current culture-based screening methods, repeated specimen collection and 
molecular-based methods of detection may help to control such outbreaks.

Taking in account the relationship between North African countries and many European countries, it is possible that the spread of NDM-1 carbapenemase may occur rapidly, mostly through $A$. baumannii rather than Enterobacteriacae, since $A$. baumannii may become much more difficult to eradicate.

\section{Acknowledgements}

We thank J M Le Glaunec for technical assistance.

\section{Conflict of interest}

None declared.

\section{Authors' contributions}

Jean-Winoc Decousser: laboratory work, manuscript preparation. Chloé Jansen: infection control, manuscript preparation. Aurélie Emirian: laboratory and clinical work. Rémy Bonnin: laboratory work. Leslie Anais: laboratory work. JeanClaude Merle: clinical work. Patrice Nordmann: manuscript preparation, analysis of data. Laurent Poirel: manuscript preparation, analysis of data.

\section{References}

1. Nordmann P, Poirel L, Walsh TR, Livermore DM. The emerging NDM carbapenemases. Trends Microbiol. 2011;19(12):588-95. http://dx.doi.org/10.1016/j.tim.2011.09.005 PMid:22078325

2. Karthikeyan K, Thirunarayan MA, Krishnan P. Coexistence of blaOXA-23 with blaNDM-1 and armA in clinical isolates of Acinetobacter baumannii from India. J Antimicrob Chemother. 2010;65(10):2253-4. http://dx.doi.org/10.1093/jac/dkq273 PMid:20650909

3. Jovcic B, Lepsanovic Z, Suljagic V, Rackov G, Begovic J, Topisirovic L, et al. Emergence of NDM-1 metallo- $\beta$ lactamase in Pseudomonas aeruginosa clinical isolates from Serbia. Antimicrob Agents Chemother. 2011;55(8):3929-31. http://dx.doi.org/10.1128/AAC.00226-11 PMid:21646490 PMCid:PMC3147624

4. Peleg AY, Seifert H, Paterson DL. Acinetobacter baumannii: emergence of a successful pathogen. Clin Microbiol Rev. 2008;21(3):538-82. http://dx.doi.org/10.1128/CMR.00058-07 PMid:18625687 PMCid:PMC2493088

5. The European Committee on Antimicrobial Susceptibility Testing (EUCAST). Breakpoint tables for interpretation of MICs and zone diameters. Version 3.1, 2013. [Accessed 10 Jul 2013]. Available from: http://www.eucast.org/ fileadmin/src/media/PDFs/EUCAST_files/Breakpoint_tables/ Breakpoint_table_v_3.1.pdf

6. Bernabeu S, Poirel L, Nordmann P. Spectrophotometrybased detection of carbapenemase producers among Enterobacteriaceae. Diagn Microbiol Infect Dis. 2012;74(1):88 90. http://dx.doi.org/10.1016/j.diagmicrobio.2012.05.021 PMid:22727768

7. Poirel L, Walsh TR, Cuvillier V, Nordmann P. Multiplex PCR for detection of acquired carbapenemase genes. Diagn Microbiol Infect Dis. 2011;70(1):119-23. http://dx.doi.org/10.1016/j. diagmicrobio.2010.12.002 PMid:21398074

8. Bonnin RA, Poirel L, Naas T, Pirs M, Seme K, Schrenzel J, et al. Dissemination of New Delhi metallo- $\beta$-lactamase-1producing Acinetobacter baumannii in Europe. Clin Microbiol Infect. 2012;18(9):E362-5. http://dx.doi.org/10.1111/j.14690691.2012.03928.x PMid:22738206

9. Vila J, Pachón J. Acinetobacter baumannii resistant to everything: what should we do? Clin Microbiol Infect. 2011;17(7):955-6. http://dx.doi.org/10.1111/j.14690691.2011.03566.x PMid:21722248

10. Silvia Munoz-Price L, Namias N, Cleary T, Fajardo-Aquino Y, Depascale D, Arheart KL, et al. Acinetobacter baumannii: association between environmental contamination of patient rooms and occupant status. Infect Control Hosp Epidemiol. 2013;34(5):517-20. http://dx.doi.org/10.1086/670209 PMid:23571370

11. Landelle C, Legrand P, Lesprit P, Cizeau F, Ducellier D, Gouot C, et al. Protracted outbreak of multidrug-resistant Acinetobacter baumannii after intercontinental transfer of colonized patients. Infect Control Hosp Epidemiol. 2013;34(2):119-24. http:// dx.doi.org/10.1086/669093 PMid:23295556

12. Haut Conseil de la Santé Publique (HCSP). Maîtrise de la diffusion des bactéries multirésistantes aux antibiotiques importées en France par des patients rapatriés ou ayant des antécédents d'hospitalisation à l'étranger. [Control of the spread of imported multi-drug resistant bacteria in France from repatriated patients or patients with history of hospitalization abroad]. Paris: HCSP; 2010. [Accessed 30 Jul 2013]. French. Available from: http://www.hcsp.fr/Explore.cgi/Telecharger?No mFichier=hcspr20101116_bmrimport.pdf

13. Hrabák J, Stolbová M, Studentová V, Fridrichová M, Chudáčková E, Zemlickova H. NDM-1 producing Acinetobacter baumannii isolated from a patient repatriated to the Czech Republic from Egypt, July 2011. Euro Surveill. 2012;17(7):pii=20085. Available from: http://www. eurosurveillance.org/ViewArticle.aspx?Articleld=20085 PMid:22370014

14. Bogaerts P, Rezende de Castro R, Roisin S, Deplano A, Huang TD, Hallin $M$, et al. Emergence of NDM-1-producing Acinetobacter baumannii in Belgium. J Antimicrob Chemother. 2012;67(6):1552-3. http://dx.doi.org/10.1093/jac/dks041 PMid:22345387

15. Boulanger A, Naas T, Fortineau N, Figueiredo S, Nordmann P. NDM-1-producing Acinetobacter baumannii from Algeria. Antimicrob Agents Chemother. 2012;56(4):2214-2215. http://dx.doi.org/10.1128/AAC.05653-11 PMid:22290985 PMCid:PMC3318329

16. Espinal P, Poirel L, Carmeli Y, Kaase M, Pal T, Nordmann P, et al. Spread of NDM-2-producing Acinetobacter baumannii in the Middle East. J Antimicrob Chemother. 2013;68(8):1928-30. http://dx.doi.org/10.1093/jac/dkt109 PMid:23674763

17. Bonnin RA, Cuzon G, Poirel L, Nordmann P. Multidrug-resistant Acinetobacter baumannii clone, France. Emerg Infect Dis. 2013;19(5):822-3. http://dx.doi.org/10.3201/eid1905.121618 PMid:23697750 PMCid:PMC3647512 